\section{Hypovitaminosis D in Children with Hashimoto's Thyroiditis}

\author{
ERGÜN SÖNMEZGÖZ ${ }^{1, a}$, SAMET OZER ${ }^{1, a}$, RESUL YILMAZ $^{1, \mathrm{a}}$, \\ YALÇIN ÖNDER ${ }^{2, a}$, ILKNUR BÜTÜN ${ }^{3, a}$, SERAP BILGE $^{1, b}$
}

\begin{abstract}
Background: Vitamin D deficiency or insufficiency may play a role in the pathogenesis of certain autoimmune diseases. Aim: To measure vitamin D levels in children with Hashimoto's thyroiditis (HT) (either with subclinical or marked hypothyroidism) and in healthy controls. Material and Methods: We included 68 children with $H$ T aged $12 \pm 4$ years ( 39 females) from a pediatric outpatient clinic and 68 healthy children aged $10 \pm 4$ years ( 37 females). Calcium metabolism parameters, thyroid function tests and anti-thyroid peroxidase (anti-TPO), anti-thyroglobulin (anti-TG) and 25 hydroxy vitamin D (25OHD) levels were measured. Results: Patients were older than controls but well matched by gender distribution. Mean 25OHD levels were significantly lower in HT patients than controls (16.8 \pm 9.3 and $24.1 \pm 9.4 \mathrm{ng} / \mathrm{mL}$ respectively, $P<0.01)$. Frequency of vitamin D deficiency was 76 and $35 \%$ in HT patients and controls, respectively $(P<0.001)$. Conclusions: Vitamin D deficiency is more common in children with HT than healthy controls.
\end{abstract}

(Rev Med Chile 2016; 144: 611-616)

Key words: Hashimoto Disease; Hypothyroidism; Vitamin D Deficiency.

\section{Hipovitaminosis D en niños con tiroiditis de Hashimoto}

Antecedentes: La deficiencia o insuficiencia de vitamina $D$ puede tener un rol en la patogenia de enfermedades autoinmunes. Objetivo: Medir niveles de vitamina $D$ en niños con tiroiditis de Hashimoto (TH) (con hipotiroidismo subclínico o marcado) y en controles sanos. Material y Métodos: Estudiamos 68 niños con $\mathrm{TH}$, de $12 \pm 4$ años (39 mujeres) y 68 controles sanos de $10 \pm 4$ años (37 mujeres). Se les midió parámetros de metabolismo de calcio, pruebas de función tiroidea, anticuerpos anti peroxidasa y anti tiroglobulina y 25 hidroxi vitamina D (25 OH vit D). Resultados: Los pacientes eran mayores que los controles pero la distribución por género era homogénea en ambos grupos. Los niveles de $25 \mathrm{OH}$ vit $\mathrm{D}$ en pacientes y controles fueron $16,8 \pm 9,3$ y 24,1 $\pm 9,4$ $n g / m L$ respectivamente, $p<0,01$. La frecuencia de deficiencia de vitamina $D$ fue de 76 y 35\% en pacientes y controles, respectivamente. Conclusiones: La deficiencia de vitamina $D$ es más común en niños con $T H$.

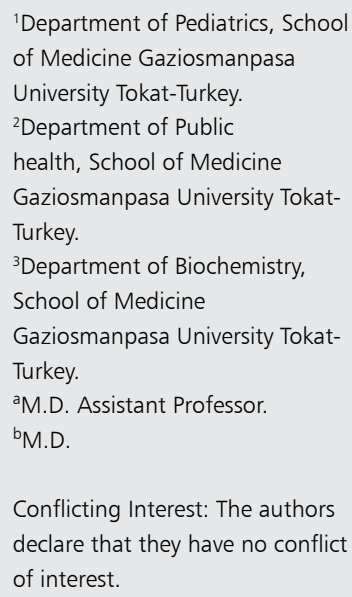

Source(s) of support: Presentation at a meeting: N/A.

Recibido el 30 de octubre de 2015, aceptado el 9 de marzo de 2016.

Corresponding Author: Ergün Sönmezgöz Gaziosmanpaşa Üniversitesi Tip Fakültesi Pediatri AD 60150 Tokat/Turkey. Phone: 00903562121001 GSM: 00905339318080 Facsimile: 00903562122142 esonmezgoz@gmail.com

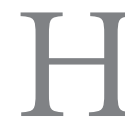
ashimoto's thyroiditis (HT) is a chronic autoimmune disease of the thyroid gland and is the most common cause of acquired hypothyroidism that presents in children and adults with or without goiter in areas where iodine deficiency is not endemic ${ }^{1}$. Worldwide annual incidence of HT is approximately $0.3-1.5 / 1,000^{2}$. Autoimmunity as well as environmental and genetic susceptibilities are important in pathogenesis. The disease is characterized by the reactivity to 
one's own thyroid antigens and both $\mathrm{T}$ and $\mathrm{B}$ cell-mediated immune responses play a role. A marked lymphocytic infiltration occurs at the thyroid tissue. Initially, the autoimmune response triggers $\mathrm{T}$ cells to release various cytokines, including interferon-gamma (INF- $\gamma$ ). These cytokines stimulate thyrocytes to form MHC-II surface antigens. Cell-mediated immunity and various antibodies result in the destruction of the thyroid tissue $^{3}$. Diagnosis is made by demonstrating high anti-TPO titer and is supported with clinical features and ultrasound findings ${ }^{1,4}$.

Vitamin D is a fat-soluble steroid molecule that exerts hormone-like effects and is either derived from the skin in the form of cholecalciferol (vitamin D3) or obtained from the diet in the form of ergocalciferol (vitamin D2). Vitamin D undergoes hydroxylation steps in the liver and kidneys and is converted to $25(\mathrm{OH})$ vitamin D3 and 1.25-dihydroxy vitamin D3 [1,25 (OH)2 D3], respectively. $25 \mathrm{OHD}$ is the best indicator of the body's vitamin D status, while 1,25 (OH) 2 D3 is the most active form ${ }^{5-9}$.

The main function of active vitamin $\mathrm{D}$ is to regulate calcium and phosphorus metabolism and maintain skeletal health. As with all steroid hormones, vitamin D exerts its effects via a nuclear receptor, vitamin D receptor (VDR), and results in transcription of various genes by affecting the promoter region of target genes. Apart from the kidneys, VDR has been identified in various cells and tissues such as skin, breast, lung, hypophysis, parathyroid gland, bone, pancreatic beta cells, gonads, brain, skeletal muscle, monocytes and macrophages ${ }^{10,11}$.

Vitamin D deficiency has been known to cause rickets by affecting bone metabolism. Currently, increased frequency of diabetes, cancer and some autoimmune diseases are also associated with vitamin $\mathrm{D}$ deficiency ${ }^{11,12}$. As a selective immune suppressant, vitamin $D$ has been shown to suppress and prevent development of autoimmune diseases such as encephalopathy, rheumatoid arthritis, systemic lupus erythematosus, type 1 diabetes mellitus and inflammatory bowel diseases ${ }^{13-15}$.

Considering the potential role of vitamin D in the pathogenesis of autoimmune diseases, in this study we evaluated vitamin D levels in children with HT. To our knowledge, only one previousstudy has analyzed vitamin D status in children with HT.

\section{Materials and Methods}

A total of 136 children were enrolled in the present study. The patient group consisted of 68 children diagnosed with $\mathrm{HT}$ in a pediatric outpatient clinic. The control group consisted of 68 age-and gender-matched children who visited the pediatric outpatient clinic for routine examinations, did not have any complaints and were healthy. In the patient group, children who had any other acute and chronic disease apart from HT were excluded from the study. Anthropometric measurements were performed in all participants and those with a BMI between the 5-85th percentilewere included in the study.

Serum calcium, phosphorus and alkaline phosphatase levels were analyzed using enzymatic methods with a COBAS 6000 AutoAnalyzer (Roche Diagnostics, USA). Thyroid stimulating hormone (TSH), free T4 (fT4), parathyroid hormone (PTH), anti-TPO, anti-TG and vitamin D levels were analyzed using chemiluminescence immunoassay methods with a COBAS C-501\&E-601 analyzer (Roche Diagnostics, USA).

HT was diagnosed by detecting high anti-TPO and anti-TG titers. Additionally, thyroid tissue was evaluated with thyroid USG. The patient group was categorized as profound hypothyroidism (PHT), subclinical hypothyroidism (SCHT) and euthyroidism (ET) depending on fT4 and TSH levels. From September to the end of November, blood samples were obtained from all individuals and vitamin D levels were analyzed. Vitamin D levels below $30 \mathrm{ng} / \mathrm{mL}$ were regarded as insufficiency, while levels below $20 \mathrm{ng} / \mathrm{mL}$ were regarded as deficiency. During the study, neither the patients nor the controls were given any drugs (anti-convulsant, hormone or anti-coagulant), vitamin supplements, calcium or any drug-like substances that could interfere with vitamin D levels.

This study was approved by the ethics committee on clinical research at Gaziosmanpasa University. All procedures were conducted in accordance with the declaration of Helsinki principles after obtaining informed consent from patients and/ or their parents.

Analyses were performed using SPSS (IBM SPSS Statistics 20, SPSS inc., IBM Co. Somers, NY, USA). Data were evaluated with descriptive statistics (mean, standard deviation) together with independent $t$-tests for comparison of the two 
groups, one-way ANOVA test forcomparison of more than two groups and a Pearson correlation test for determination of associations between variables. $\mathrm{P}<0.05$ was considered to indicate statistical significance.

\section{Results}

This study consisted of 68 patients diagnosed with HT in Gaziosmanpasa University Pediatrics Clinic between 2010 and 2014 and 68 healthy, age and gender-matched children. The mean age in the patient group was $12.15 \pm 4.06$ years ( 39 females, 29 males) and $10.09 \pm 4.44$ years in the control group (37 females, 31 males; $\mathrm{P}<0.05$ (Table 1 ).

The mean 25OHD level in the patient group was significantly lower than in the control group $(16.85 \pm 9.26$ vs $24.13 \pm 9.4 \mathrm{ng} / \mathrm{mL} ; \mathrm{P}<0.001$ (Figure 1). The frequency of vitamin D deficiency was $76 \%$ in the HT group and 35\% in the control group $(\mathrm{P}<0.001$ (Table 2$)$. Among the patients with HT, 5 (7.4\%) had PHT, 32 (47.1\%) SCHT and $31(45.6 \%)$ ET. All HT patients who had PHT were vitamin $\mathrm{D}$-deficient. The mean vitamin $\mathrm{D}$ levels were $14.7 \mathrm{ng} / \mathrm{mL}$ in patients with PHT $(\mathrm{n}=5)$, $18.8 \mathrm{ng} / \mathrm{mL}$ in patients with SCHT $(\mathrm{n}=32)$ and $15.1 \mathrm{ng} / \mathrm{mL}$ in patients with ET $(\mathrm{n}=31)$. Although patients with PHT had low vitamin D levels, there was no statistical difference between PHT, SCHT and ET. Anti-TPO and vitamin D levels were negatively correlated in patients with HT although without statistical significance $(r=-0.22$, $\mathrm{P}=0.065)$. Vitamin D and PTH levels were correlatedin patients with $\mathrm{HT}(\mathrm{r}=-0.32, \mathrm{P}=0.006)$. There was no statistically significant correlation between vitamin $\mathrm{D}$ and TSH levels $(\mathrm{r}=-0.105$, $\mathrm{P}=0.3$ ). Vitamin $\mathrm{D}$ levels were not significantly associated with calcium, phosphorus, ALP or PTH levels.

\section{Discussion}

$\mathrm{HT}$ is the most common endocrine disease in children ${ }^{16}$. Although autoimmunity is important in HT pathogenesis, genetic and environmental factors playa role. The disease, in which cellular and humoral immune responses occur at varying degrees, is characterized by a progressive destruction of the thyroid tissue. Pathologically, thyroid
Table 1. Age, sex and plasma 25(OH)D status of the hasimoto's thyroiditis and control groups

\begin{tabular}{|lccc|}
\hline & $\begin{array}{c}\text { Case } \\
(\mathbf{n = 6 8 )}\end{array}$ & $\begin{array}{c}\text { Control } \\
(\mathbf{n = 6 8 )}\end{array}$ & p \\
Age (years) & $12.15 \pm 4.06$ & $10.09 \pm 4.44$ & $<0.05$ \\
Sex n (\%) & & & \\
Female & $39(57)$ & $37(54)$ & 0.47 \\
Male & $29(42)$ & $31(45)$ & \\
25OHD $(\mathrm{ng} / \mathrm{mL})$ & $16.8 \pm 9.2$ & $24.1 \pm 9.4$ & $<0.001$ \\
\hline
\end{tabular}

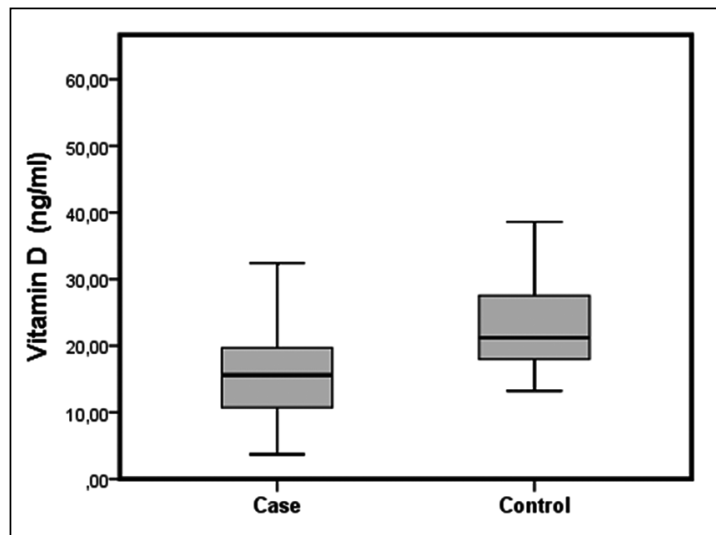

Figure 1. Vitamin $D$ levels in hasimoto's thyroiditis and control groups $(P<0.001)$.

Table 2. Frequency distribution of categorical vitamin $D$ in study subject

\begin{tabular}{|lccc|}
\hline & $\begin{array}{c}\text { Case } \\
(\mathbf{n}=\mathbf{6 8})\end{array}$ & $\begin{array}{c}\text { Control } \\
(\mathbf{n}=\mathbf{6 8})\end{array}$ & Total \\
\hline Vitamin D deficiency & $52(76)$ & $24(35)$ & $76(56)$ \\
Vitamin D insufficiency & $9(13)$ & $30(44)$ & $39(29)$ \\
Normal & $7(10)$ & $14(20)$ & $21(15)$ \\
\hline
\end{tabular}

tissue is distinguishedby profound T lymphocyte infiltration ${ }^{3,17,18}$.

Apart from the effect of active vitamin D on calcium, phosphorus and bone metabolism, vitamin $\mathrm{D}$ has immune regulatory and anti-inflammatory functions ${ }^{19}$. Vitamin $\mathrm{D}$ exerts its biological effects via vitamin D receptor (VDR) on the target cells ${ }^{8,20}$. VDR has been identified in all immune system cells. Furthermore, the 
enzyme 1-alpha-hydroxylase has been detected in various tissues and 1,25 $(\mathrm{OH}) 2 \mathrm{D} 3$ is produced extra-renally via paracrine action, suggesting that vitamin $D$ could have many functions outside the skeletal system including roles in endocrine disea$\operatorname{ses}^{21-23} \cdot 1,25(\mathrm{OH}) 2 \mathrm{D} 3$ is an important immune system regulator, modulating $B$ and $T$ lymphocyte function $\mathrm{s}^{24,25}$. The immune-modulatory function of active vitamin $\mathrm{D}$ is attributed to its effects on innate and adaptive system cells. 1,25 (OH)2D3 inhibits $\mathrm{T}$ cell proliferation via IL-2, IFN- and IL-17 ${ }^{26,27}$. Studies suggest $1,25(\mathrm{OH}) 2 \mathrm{D} 3$ may prevent development or attenuate signs of autoimmune, inflammatory, infectious and cardiac diseases as well as cancer $8,22,24,28$. In recent years, researchers have focused on understanding the non-calcemic role of vitamin $\mathrm{D}$ on the immune system and, especially, $T$ cell-mediated immunity. Tamer et al..$^{29}$ found low vitamin D levels in adult patients with HT and high prevalence of vitamin D insufficiency. In a similar study, Kivity et al. ${ }^{12}$ found a higher ratio of vitamin D deficiency $(<10$ $\mathrm{ng} / \mathrm{mL}$ ) in patients with HT compared with the controls. Nasrin Mansoruni et al. ${ }^{30}$ had similar results. In a study conducted on a childhood age group, Çamurdan et al. ${ }^{31}$ found a higher frequency of vitamin D deficiency in the HT patients than controls. In our study, the ratio of vitamin D deficiency was higher in the patient group than the control group. To the best of our knowledge, our study is the second study on childhood age patients involving children with the autoimmune disease HT. Our study indicated that vitamin D deficiency rate is high among children with HT.

In our study, vitamin D andanti-TPO levels were negatively correlated, although without statistical significance. Anti-TPO and anti-TG appear independent of vitamin $\mathrm{D}$ pathophysiologically. However, the association between vitamin $\mathrm{D}$ deficiency and anti-TPO shown in previous studies appearsto be related only to severe deficiency of vitamin $\mathrm{D}^{12,32-35}$. In one study where vitamin $\mathrm{D}$ deficiency was defined as levels $<20 \mathrm{mg} / \mathrm{dL}$, there was no associationbetween vitamin $\mathrm{D}$ and anti-TPO.

Patients with HT who are euthyroid and asymptomatic at the time of diagnosis develop hypothyroidism within a number of years ${ }^{3,14,36,37}$. An interesting finding in our study was that all HT patients with PHT had low levels of vitamin D. Similar to our results, previous studies reported lower vitamin D levels in patients with PHT than controls, and a positive correlation between vitamin D deficiency and TSH levels. However, those studies did not report a significant difference between hypothyroidism groups with regard to the association between vitamin D levels and TSH. This condition may be explained by euthyroidism in patients with HT at the time of diagnosis and disturbance of thyroid function tests over a long period of time.

Currently, vitamin D is recognized as necessary for optimal health. Apart from calcium and phosphorus metabolism, vitamin D may play an important role in the pathogenesis of various autoimmune, degenerative and inflammatory diseases and cancer ${ }^{15,22}$. However, there is no consensus on the optimal serum vitamin D concentrations for bone health and prevention of extra-skeletal diseases $^{6,38,39}$. Currently, serum vitamin D levels above $30 \mathrm{ng} / \mathrm{mL}$ are considered the most beneficial for maintenance of bone health. However, data regarding the recommended daily amount of vitamin D necessary to achieve these levels is contradictory ${ }^{8,38}$.

Vitamin D levels are influenced by various factors such as geographic differences, seasonal changes, time spent outdoors and traditional clothing habits. Low levels of vitamin D in some autoimmune and chronic diseases may be attributed to insufficient outdoor activities due to present diseases (i.e., SLE, MS, RA, cancer), malabsorption (inflammatory bowel diseases) and long-term use of corticosteroids $s^{5,8,40,41}$. Factors such as these that could affect vitamin D levels are unlikely in HT subjects.

Our study had several limitations. First, statistical evaluation regarding feeding and clothing habits and time spent outdoors was not possible. Second, a statistically significant difference with regard to age was observed between the patients and the controls who visited our outpatient clinic for routine check-ups.

In conclusion, vitamin D deficiency is common in children with HT. The correlation between vitamin $\mathrm{D}$ and anti-TPO appears related to severe vitamin $\mathrm{D}$ deficiency. Although vitamin D levels are influenced by various factors, studies from different geographical regions found higher rates of vitamin $\mathrm{D}$ deficiency in many autoimmune diseases compared with controls. Our findings suggest vitamin $\mathrm{D}$ may have a significant role in the pathogenesis of the autoimmune disease HT. 
Future studies should focus on the utilization of vitamin $\mathrm{D}$ for reducing symptoms and preventing $\mathrm{HT}$ as well as on its protective roles.

Acknowledgement: The English in this document has been checked by at least two professional editors, both native speakers of English. For a certificate, please see: http://www.textcheck.com/ certificate/3I $3 \mathrm{nBK}$

\section{References}

1. Caturegli P, De Remigis A, Rose NR. Hashimoto thyroiditis: clinical and diagnostic criteria. Autoimmun Rev 2014; 13 (4-5): 391-7.

2. Iddah MA, Macharia BN. Autoimmune thyroid disorders. ISRN Endocrinol 2013. 2013: 509-764.

3. Dayan CM, Daniels GH. Chronic autoimmune thyroiditis. N Engl J Med 1996; 335 (2): p. 99-107.

4. Pyzik A, Grywalska E, Matyjaszek-Matuszek B, Rolinski J. Immune disorders in Hashimoto's thyroiditis: what do we know so far? J Immunol Res 2015; 979167.

5. Muszkat P, Camargo MB, Griz LH, Lazaretti-Castro M. Evidence-based non-skeletal actions of vitamin D. Arq Bras Endocrinol Metabol 2010; 54 (2): 110-7.

6. Holick MF, Binkley NC, Bischoff-Ferrari HA, Gordon CM, Hanley DA, Heaney RP, et al. Evaluation, treatment, and prevention of vitamin D deficiency: an Endocrine Society clinical practice guideline. J Clin Endocrinol Metab 2011; 96 (7): 1911-30.

7. Cantorna MT, Zhao J, Yang L. Vitamin D, invariant natural killer T-cells and experimental autoimmune disease. Proc Nutr Soc 2012; 71 (1): 62-6.

8. Misra M, Pacaud D, Petryk A, Collett-Solberg PF, Kappy M. Vitamin D deficiency in children and its management: review of current knowledge and recommendations. Pediatrics 2008; 122 (2): 398-417.

9. Tripkovic L, Lambert H, Hart K, Smith CP, Bucca G, Penson S, et al. Comparison of vitamin D2 and vitamin D3 supplementation in raising serum 25-hydroxyvitamin D status: a systematic review and meta-analysis. Am J Clin Nutr 2012; 95 (6): 1357-64.

10. Samuel S, Sitrin MD. Vitamin D's role in cell proliferation and differentiation. Nutr Rev 2008; 66 (10): S11624.

11. Dastani Z, Li R, Richards B. Genetic regulation of vitamin D levels. Calcif Tissue Int 2013; 92 (2): 106-17.

12. Kivity S, Agmon-Levin N, Zisappl M, Shapira Y, Nagy EV, Danko K, et al. Vitamin D and autoimmune thyroid diseases. Cell Mol Immunol 2011; 8 (3): 243-7.

13. Deluca HF, Cantorna MT. Vitamin D: its role and uses in immunology. FASEB J 2001; 15 (14): 2579-85.

14. Hypponen E, Laara E, Reunanen A, Jarvelin MR, Virtanen SM. Intake of vitamin $\mathrm{D}$ and risk of type 1 diabetes: a birth-cohort study. Lancet 2001; 358 (9292): 1500-3.

15. Kamen DL, Cooper GS, Bouali H, Shaftman SR, Hollis BW, Gilkeson GS. Vitamin D deficiency in systemic lupus erythematosus. Autoimmun Rev 2006; 5 (2): 114-7.

16. Shapira Y, Agmon-Levin N, Shoenfeld Y. Geoepidemiology of autoimmune rheumatic diseases. Nat Rev Rheumatol 2010; 6 (8): 468-76.

17. Mazokopakis EE, Kotsiris DA. Hashimoto's autoimmune thyroiditis and vitamin D deficiency. Current aspects. Hell J Nucl Med 2014; 17 (1): 37-40.

18. Muscogiuri G, Mitri J, Mathieu C, Badenhoop K, Tamer $\mathrm{G}$, Orio F, et al. Mechanisms in endocrinology: vitamin $\mathrm{D}$ as a potential contributor in endocrine health and disease. Eur J Endocrinol 2014; 171 (3): R101-10.

19. DeLuca HF. Is there more to learn about functional vitamin D metabolism? J Steroid Biochem Mol Biol 2015; 148: 3-6.

20. DeLuca HF. Overview of general physiologic features and functions of vitamin D. Am J Clin Nutr 2004; 80 (6 Suppl): 1689S-96S.

21. Muscogiuri G, Mitri J, Mathieu C, Badenhoop K, Tamer $\mathrm{G}$, Orio F, et al. Mechanisms in endocrinology: vitamin $\mathrm{D}$ as a potential contributor in endocrine health and disease. Eur J Endocrinol 2014; 171 (3): R101-10.

22. Deluca HF. History of the discovery of vitamin $D$ and its active metabolites. Bonekey Rep 2014; 3: 479.

23. Wang J, Lv S, Chen G, Gao C, He J, Zhong H, et al. Meta-analysis of the association between vitamin D and autoimmune thyroid disease. Nutrients 2015; 7 (4): 2485-98.

24. Cantorna MT, Zhu Y, Froicu M, Wittke A. Vitamin D status, 1,25-dihydroxyvitamin D3, and the immune system. Am J Clin Nutr 2004; 80 (6 Suppl): 1717S-20S.

25. Yin K, Agrawal DK. Vitamin D and inflammatory diseases. J Inflamm Res 2014; 7: 69-87.

26. Cantorna MT, Snyder L, Lin YD, Yang L. Vitamin D and 1,25(OH)2D regulation of T cells. Nutrients 2015; 7 (4): 3011-21.

27. Bruce D, Yu S, Ooi JH, Cantorna MT. Converging pathways lead to overproduction of IL-17 in the absence of vitamin D signaling. Int Immunol 2011; 23 (8): 519-28.

28. Cantorna MT, Mahon BD. Mounting evidence for vitamin $\mathrm{D}$ as an environmental factor affecting autoimmune disease prevalence. Exp Biol Med (Maywood) 2004; 229 (11): 1136-42.

29. Tamer G, Arik S, Tamer I, Coksert D. Relative vitamin D insufficiency in Hashimoto's thyroiditis. Thyroid 2011; 21 (8): 891-6. 
30. Mansournia N, Mansournia MA, Saeedi S, Dehghan J. The association between serum $25 \mathrm{OHD}$ levels and hypothyroid Hashimoto's thyroiditis. J Endocrinol Invest 2014; 37 (5): 473-6.

31. Camurdan OM, Doger E, Bideci A, Celik N, Cinaz P. Vitamin D status in children with Hashimoto thyroiditis. J Pediatr Endocrinol Metab 2012; 25 (5-6): 467-70.

32. Zaidman VE, Maceiras M, Lazzati JM, Kutasz EP, D'Isa G, Chilleli C, et al. High prevalence of anti-thyroid antibodies associated with a low vitamin $\mathrm{D}$ status in a pediatric cohort. Clin Chem Lab Med 2014; 52 (6): e119-22.

33. Bozkurt NC, Karbek B, Ucan B, Sahin M, Cakal E, Ozbek $\mathrm{M}$, et al. The association between severity of vitamin D deficiency and Hashimoto's thyroiditis. Endocr Pract 2013; 19 (3): 479-84.

34. Shin DY, Kim KJ, Kim D, Hwang S, Lee EJ. Low serum vitamin $\mathrm{D}$ is associated with anti-thyroid peroxidase antibody in autoimmune thyroiditis. Yonsei Med J 2014; 55 (2): 476-81.

35. Goswami R, Marwaha RK, Gupta N, Tandon N, Sreenivas V, Tomar N, et al. Prevalence of vitamin D deficiency and its relationship with thyroid autoimmunity in Asian Indians: a community-based survey. Br J Nutr 2009; 102 (3): 382-6.
36. De Luca F, Santucci S, Corica D, Pitrolo E, Romeo M, Aversa T. Hashimoto's thyroiditis in childhood: presentation modes and evolution over time. Ital J Pediatr 2013; 39: 8.

37. Demirbilek H, Kandemir N, Gonc EN, Ozon A, Alikasifoglu A. Assessment of thyroid funct.on during the long course of Hashimoto's thyroiditis in children and adolescents. Clin Endocrinol (Oxf) 2009; 71 (3): 451-4.

38. Bischoff-Ferrari HA, Giovannucci E, Willett WC, Dietrich T, Dawson-Hughes B. Estimation of optimal serum concentrations of 25-hydroxyvitamin $\mathrm{D}$ for multiple health outcomes. Am J Clin Nutr 2006; 84 (1): 18-28.

39. Stein EM, Laing EM, Wilson AMR, Modlesky CM, Kimlin MG, Hall DB, et al. Serum 25-hydroxy-vitamin $\mathrm{D}$ levels and bone in prepubertal females living in a southern latitude. Faseb Journal 2005; 19 (4): A60-A60.

40. Grant WB, Holick MF. Benefits and requirements of vitamin D for optimal health: a review. Altern Med Rev 2005; 10 (2): 94-111.

41. Peracchi OA, Terreri MT, Munekata RV, Len CA, Sarni RO, Lazaretti-Castro M, et al. Low serum concentrations of 25-hydroxyvitamin D in children and adolescents with systemic lupus erythematosus. Braz J Med Biol Res 2014; 47 (8): 721-6. 